\title{
14
}

\section{Pollen evidence for plant introductions in a Polynesian tropical island ecosystem, Kingdom of Tonga}

\author{
Patricia L. Fall \\ School of Geographical Sciences, Arizona State University, Tempe, United States \\ FALL@asu.edu
}

\section{Introduction}

The dynamic nature of tropical Pacific ecosystems results from chance migrations and the evolution of founder species, as well as from physical factors such as changes in sea level, ocean currents, tectonic processes and climate (Hope 2001). In addition, this region's vegetation is constantly adjusting through succession to local perturbations like landslides and tropical cyclones. These ecological and physical processes are compounded by continued immigration of new species, competition, extinctions and extirpation of species. For many island ecosystems the most dramatic impact on species composition results from the arrival of humans and their 'co-voyaging' plants and animals (Hope 2001). The degree to which climatic or other natural variations, versus human impacts, have caused recent environmental fluctuations in island ecosystems is an ongoing debate (cf. Nunn 1994; Burney 1997).

In this paper, I examine palynological evidence for plants introduced to several islands in the three main island groups of Tongatapu, Ha'apai and Vava'u in the Kingdom of Tonga. My purpose is to briefly document the history of the tropical rainforests of Tonga as they can be reconstructed from pollen cores, to understand the role that humans played in the development of the Tongan flora, and to discuss plant introductions to the islands by both Polynesian and later European settlers.

Losses or increases in plant species on remote islands are controlled by many factors, including habitat change, natural factors, and loss of dispersers or pollinators. Habitat change in Pacific tropical ecosystems may be due to human factors, including fire, habitat destruction (deforestation) and the introduction of exotic animals or plants (Southern 1986; Hope and Pask 1998; Stevenson 1998; Hope et al. 1999; Haberle et al. 2001; Stevenson et al. 2001; Haberle 2007). Natural factors such as tropical cyclones (Franklin et al. 2004), sea-level variation (Dickinson et al. 1994; Dickinson 2001, 2003), or the effects of ENSO (Haberle and David 2004) cause disturbances to island ecosystems. The loss of animal pollinators or dispersers, triggered by human or natural causes, can further disrupt reproduction and establishment 
of plant species (McConkey and Drake 2006, 2007; Steadman 2006; Prebble and Dowe 2008). As Hope (2001) points out, tropical Pacific islands support rain-green forests with relatively high numbers of endemic species. Variations in local species diversity and ecological adaptations between island groups confound the task of understanding present vegetation dynamics, and make deciphering palaeoecological interactions a particularly daunting task. Thus, palaeoecological data often are needed to help unravel the history of an island's ecology. Here, I address one of the historical questions regarding Pacific ecosystems asked by Hope (2001:172): Have human populations caused major changes in species composition and ecological processes?

\section{Kingdom of Tonga}

The Kingdom of Tonga, lying southwest of Samoa and east of Fiji, is comprised of more than 170 islands and covers a vast area of the south Pacific Ocean from $15^{\circ} 30^{\prime}$ to $22^{\circ} 20^{\prime}$ S latitude, and between $173^{\circ} 00^{\prime}$ and $177^{\circ} 15^{\prime} \mathrm{W}$ longitude (Figure 1). Tonga is formed by a north-south alignment of islands that includes the three main uplifted limestone island groups of Vava'u, Haapai and Tongatapu. The Tofua Volcanic Arc to the west of these limestone islands is made up of the younger volcanic islands and sea mounts that run from the northernmost island of Niuafo'ou to 'Ata in the south. The highest point in the archipelago is Koa, an extinct volcano with an elevation of $1046 \mathrm{~m}$. Recent eruptions and earthquakes, including an eruption of a submarine volcano on March 19, 2009, southwest of Tongatapu, demonstrate the ongoing volcanic and tectonic activity of the islands.

The Kingdom of Tonga has a mild tropical maritime climate dominated by the south Pacific trades for most of the year. Annual temperature and precipitation average $21^{\circ} \mathrm{C}$ and $1780 \mathrm{~mm}$ on Tongatapu, and $23.5^{\circ} \mathrm{C}$ and $2340 \mathrm{~mm}$ on Vava'u (Thompson 1986). The climate is slightly wetter in the Austral summer than in the somewhat drier and cooler winter. The islands lie in the track of tropical cyclones, being struck by an average of two tropical cyclones per year (Franklin et al. 2004).

Tonga is part of the southwestern Pacific region of the Indo-Malesian floral realm described by van Steenis (1979) in which floral impoverishment increases with distance from tropical Southeast Asia. Tropical shoreline vegetation is typical of many Pacific islands (Whistler 1992a). More species-rich lowland rainforests are found on the larger islands (Tongatapu, 'Eua and Vava'u), with somewhat more depauperate forests in Ha'apai and on the smaller islands. The islands of 'Eua and 'Uta Vava'u contain more diverse forests due to their larger sizes and greater elevational range (more than $300 \mathrm{~m}$ ) (Figure 2). A range of botanical inventories document the flora of Tonga (Yuncker 1959; Sykes 1977, 1981; Palmer 1988; Stoddart 1992; Whistler 1992a, 1992b; Drake et al. 1996; Mueller-Dombois and Fosberg 1998; Franklin et al. 1999; Park and Whistler 2001; Wiser et al. 2002; Franklin 2003; Franklin et al. 2006). Park and Whistler (2001) estimate Tonga has about 450 indigenous and 240 introduced plant species. Polynesian introductions (about 40 species) to Tonga tend to be trees or herbaceous cultigens that are dispersed by people or native fauna, whereas European introductions (as many as 200 species) are primarily herbaceous species that are dispersed by wind or epizoochorously by humans or their domestic animals (Fall et al. 2007). Nomenclature (including Tongan and English names where known) follows Smith $(1979,1981,1985,1988,1991)$ and Whistler (1991) (Table 1). 


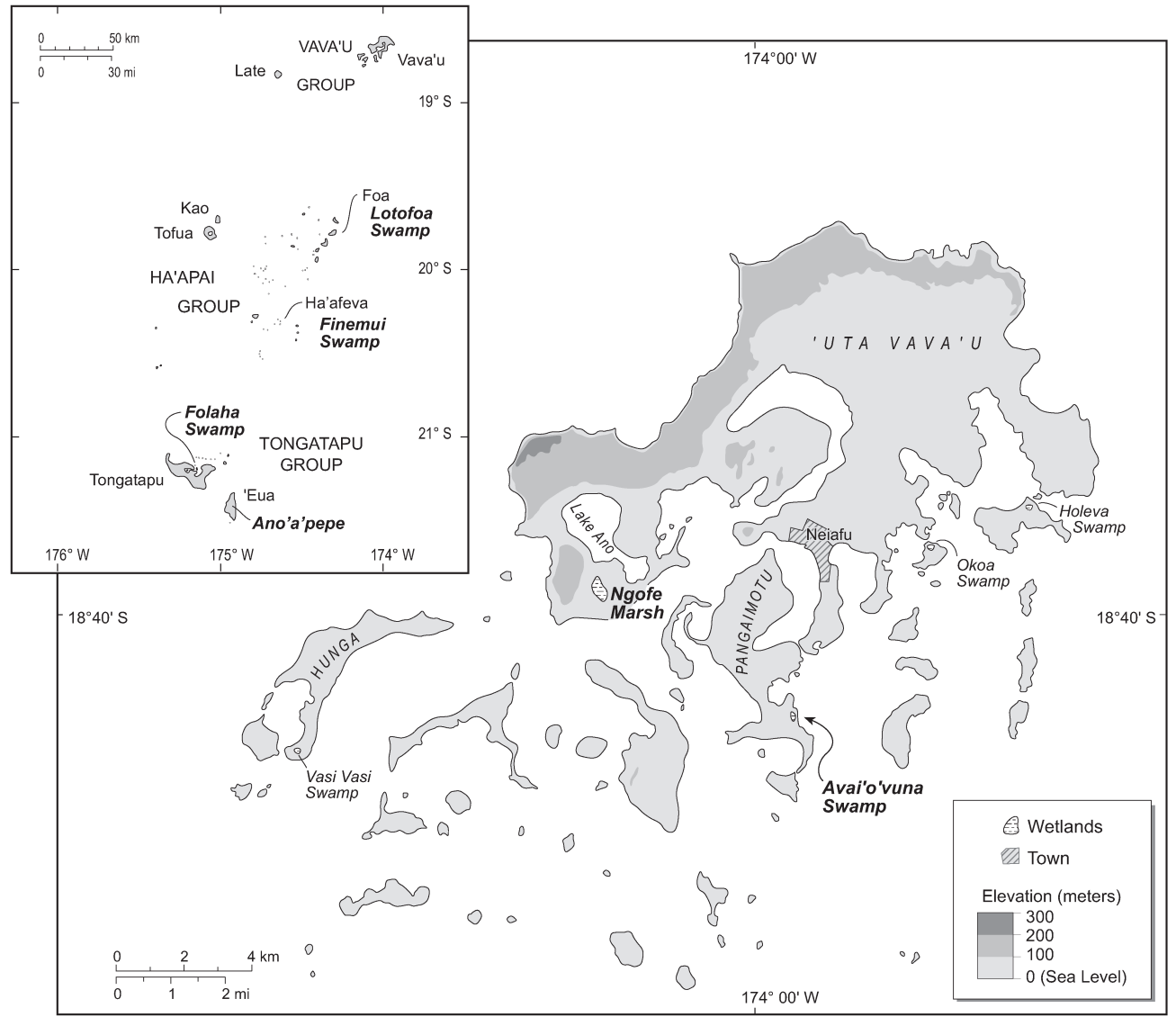

Figure 1. Location of the Kingdom of Tonga. Large map shows the Vava'u island group with the location of the Ngofe Marsh and the Avai'o'vuna Swamp. Inset shows three main island groups (Vava'u, Ha'apai and Tongatapu) where sediment cores were collected. Ha'apai island group: Lotofoa Swamp on Foa, and Finemui Swamp on Ha'afeva. Tongatapu island group: Folaha Swamp in Fanga 'Uta Lagoon on Tongatapu, and Ano'ápepe on 'Eua (see Table 2 for descriptions of coring localities). Figure by Barbara Trapido-Lurie

Figure 2. Rainforest on 'Uta Vava'u. Photograph by P. Fall

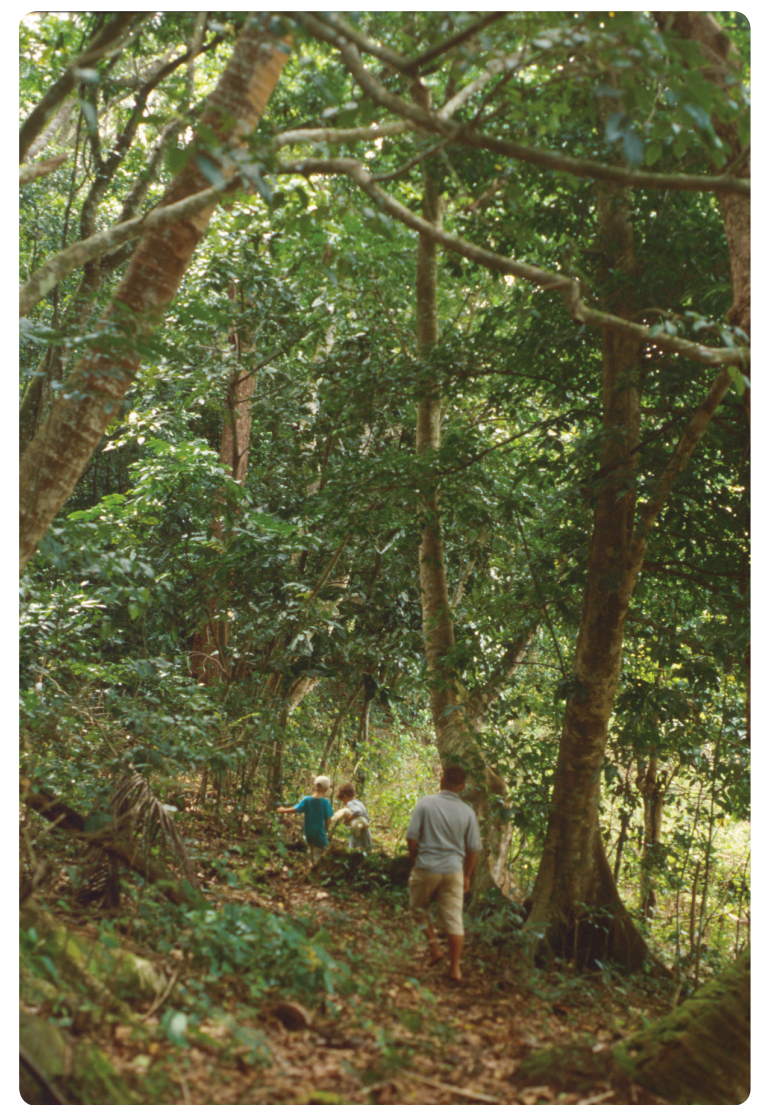


Table 1. Plant taxa mentioned in text including scientific authorities, Tongan and English names (where known). Nomenclature follows Smith $(1979 ; 1981 ; 1985 ; 1988 ; 1991)$ and Whistler (1991) (Table 1 continues on page 257)

\begin{tabular}{|c|c|}
\hline Taxon & (Tongan; English names) \\
\hline Acrostichum aureum $\mathrm{L}$. & (hakato; golden leatherfern) \\
\hline Alphitonia zizyphoides (Spreng.) A. Gray & (toi) \\
\hline Alternanthera sessilis R. Br. ex DC & (loseli; joyweed) \\
\hline Barringtonia asiatica (L.) Kurz & (futu; fish poison tree) \\
\hline Bruguiera gymnorrhiza (L.) Lam. & (tongo lei) \\
\hline Calophyllum inophyllum L. & (feta $u$; beach mahogany; oil nut tree) \\
\hline Calophyllum neo-ebudicum Guillaumin & $(\operatorname{tamanu})$ \\
\hline Canarium harveyi var. harveyi Leenh. & ('ai) \\
\hline Casuarina equisetifolia J.R. \& G. Forst. & (toa; ironwood; she-oak) \\
\hline Cocos nucifera $\mathrm{L}$. & (nui; coconut) \\
\hline Colocasia esculenta (L.) Schott. & (talo; taro) \\
\hline Cordyline fruticosa (L.) A. Chev. & (si; ti; good luck plant) \\
\hline Cyperaceae & (sedge family) \\
\hline Dysoxylum forsteri (Juss.) DC & (mo'ota) \\
\hline Dysoxylum tongense A.C. Smith & (mo'ota mea) \\
\hline Elaeocarpus tonganus Burk. & (ma'ama'alava; blue berry tree) \\
\hline Eleocharis dulcis (Burm. f.) Trin. ex Hensch. & (kutu; water chestnut) \\
\hline Ellatostachys falcata (Seem.) Radlk. & (ngatata) \\
\hline Erianthus & (plume grass) \\
\hline Erythrina fusca Lour. & (ngatae fisi; Fijian coral tree) \\
\hline Erythrina variegata $\mathrm{L}$. & (ngatae; coral tree) \\
\hline Excoecaria agallocha $\mathrm{L}$. & (feta'anu; blind-your-eye mangrove) \\
\hline Flacourtiaceae & (Flacourtiaceae family) \\
\hline Freycentia urvilleana Hombron \& Jacqinot & (kahikahi) \\
\hline Gardenia augusta (L.) Merr. & (siale matalateau; double gardenia) \\
\hline Gardenia tannaensis Guillaumin & (siale lotuma; gardenia) \\
\hline Gardenia taitensis DC. Prodr. & (Tahitian gardenia) \\
\hline Garuga floribunda Decne. & (manaui) \\
\hline Glochidion ramiflorum J.R. \& G. Forst. & (manolo) \\
\hline Guettarda speciosa $\mathrm{L}$. & (риориа; beach gardenia) \\
\hline \multicolumn{2}{|l|}{ Hedycarya dorstenioides A. Gray } \\
\hline Hernandia nymphaeifolia (Presl) Kub. & (fotulona; lantern tree) \\
\hline Hibiscus tiliaceus $\mathrm{L}$. & (fau; beach hibiscus) \\
\hline Homalanthus nutans Benth. \& Hook. f. ex Drake & (fonua mamala; bleeding heart tree) \\
\hline Homalium & $($ moto $)$ \\
\hline Inocarpus fagifer (Parkinson) Fosb. & (iff; Tahitian chestnut) \\
\hline Ipomoea batatas L. & (kumala; sweet potato) \\
\hline Leguminosae & (legume family) \\
\hline Lepironia articulata (Retz.) Domin & (kutu kofe; blue rush) \\
\hline Ludwigia octovalvis (Jacq.) Raven & (loaana; water primrose) \\
\hline Macaranga haveyana (Muell. Arg.) Muell. Arg. & (loupata; giant leaf plant) \\
\hline Mallotus & (kamala tree) \\
\hline Malvaceae & (mallow family) \\
\hline Maniltoa grandiflora (A.Gray) Scheff. & (pekepeka; dove tree; handkerchief tree) \\
\hline Melastomataceae & (Melastomataceae family) \\
\hline Meliaceae & (Meliaceae family) \\
\hline Mimosa pudica L. & (mateloi; sensitive plant) \\
\hline Miscanthus floridus (Labill.) Warb. & (kaho tonga; reed) \\
\hline Monimiaceae & (Monimiaceae family) \\
\hline Moraceae & (fig family) \\
\hline Morinda citrifolia L. & (nonu; Indian mulberry) \\
\hline Narenga & (genus in the grass family) \\
\hline Neonauclea fosteri (Seem.) Merr. & $(a f a)$ \\
\hline Onagraceae & (primrose family) \\
\hline
\end{tabular}




\begin{tabular}{|c|c|}
\hline Taxon & (Tongan; English names) \\
\hline Pandanus tectorius Parkinson & (fafa; screw-pine) \\
\hline Pandanus veitchii Hort. & (hanaii) \\
\hline Pandanus whitmeeanus Mart. & (paongo) \\
\hline Papillionaceae & (pea family) \\
\hline \multicolumn{2}{|l|}{ Phyllanthus amicorum G.L. Webster } \\
\hline Pinus caribaea Morelet & (paini; Caribbean pine) \\
\hline Planchonella & $($ kalaka) \\
\hline Pleiogynium timoriense (DC.) Leehn. & (tangato or Burdekin plum) \\
\hline Poaceae & (grass family) \\
\hline Podocarpus pallidus N.E. Gray & (uhiuhi) \\
\hline Polygonum dichotomum Bl. Bijar (synonym Polygonum glabrum) & (dense-flower knotweed) \\
\hline Pometia pinnata J.R. \& G. Forst. & (tava; island lychee) \\
\hline Psidium guajava $\mathrm{L}$. & (kuava; guava) \\
\hline Rhizophora mangle & (tongo; mangrove) \\
\hline Rhus taitensis Guillemin & (tavahi; island sumac) \\
\hline Saccharum officinarum L. & (to; sugarcane) \\
\hline Saccharum spontaneum L. & (wild sugarcane) \\
\hline Sapotaceae & (sapote family) \\
\hline Schizostachyum glaucifolium (Rupr.) Munro & (kofe; bamboo; Polynesian 'ohe) \\
\hline Sclerostachys & (genus in the grass family) \\
\hline Solanum amicorum Benth. & (polo tonga) \\
\hline \multicolumn{2}{|l|}{ Solanum nigrum $\mathrm{L}}$. \\
\hline Stachytarpeta urticifolia (Salisb.) Sims & (biku 'i kuma; blue rat's-tail) \\
\hline Stenochlaena palustris (Burm.) Beddome & (pasivaka; climbing fern) \\
\hline Syzygium & $(f e k i k a)$ \\
\hline Thespesia populnea (L.) Solander ex Correa & (milo; portia tree) \\
\hline Trema cannabina Lour. & (mangele; poison bush) \\
\hline Tricale & (grass hybrid of Triticum and Secale) \\
\hline Triumfetta rhomboidea Jacq. & (mo'osipo; burr bush) \\
\hline Urticaceae & (nettle family) \\
\hline
\end{tabular}

Polynesian settlers reached Tonga by 2850 yr BP (Burley 1998). Lapita culture has been documented on Tongatapu (Poulsen 1987; Burley and Dickinson 2001), Ha'apai (Burley 1994; Burley et al. 1999) and Vava'u by about 2700-2800 yr BP (Burley and Connaughton 2007). European contact with Tonga was initiated by Dutch sailors in 1616 and by Abel Tasman in 1643 (Whistler 1991). The next European contact was made by James Cook in 1773, 1774 and 1777; missionary settlement soon followed in the late 1700s. Only 37 of the islands are inhabited today, with the majority of the Tongan people living on the main islands of Tongatapu, Ha'apai, or 'Uta Vava'u, the largest island of Vava'u.

\section{Palynological records from Tonga}

Sediment cores have been retrieved from a variety of small wetlands found throughout the Kingdom of Tonga (Table 2). Sediments were collected by the author on several islands in the Vava'u Island Group in 1997 and 1998, including cores from the islands of Pangaimotu (Avai'ovvuna Swamp) and 'Uta Vava'u (Ngofe Marsh) (Fall 2005). In the Ha'apai Islands, Flenley and others (1999) collected cores from two small basins on the islands of Haafeva (Finemui Swamp) and Foa (Lotofoa Swamp). In the Tongatapu island group, a sediment core was collected from the island of 'Eua in 1998 from a small lake in the highlands, Ano'a'pepe (Lake of the Butterflies) (Fall unpublished). In addition, Ellison (1989) reported on a series of sediment cores from a mangrove swamp on the main island of Tongatapu. 
The evidence for indigenous or pre-Polynesian vegetation, Polynesian plant introductions and later European-introduced plants from these sediment records will be used to outline floral changes in Tonga over about the past 7000 years. Particular attention is directed to Polynesian and European plant introductions, as documented by pollen records in Tonga, and to plant taxa showing substantial declines or increases in abundance associated with Lapita colonisation through later European settlement.

Table 2. Sediment cores collected for pollen analyses in the Kingdom of Tonga

\begin{tabular}{|c|c|c|c|c|c|c|c|}
\hline \multicolumn{8}{|l|}{ Island Group } \\
\hline Core locality & Island & Latitude & Longitude & $\begin{array}{l}\text { Elevation } \\
(\mathrm{m})\end{array}$ & $\begin{array}{l}\text { Approximate } \\
\text { age range }\end{array}$ & $\begin{array}{l}\text { Length of } \\
\text { core }(\mathrm{m})\end{array}$ & Reference \\
\hline \multicolumn{8}{|c|}{ Vegetation surrounding coring locality } \\
\hline \multicolumn{8}{|c|}{ Vava'u Island Group } \\
\hline Ngofe Marsh & 'Uta Vava’u & $18^{\circ} 39^{\prime} 53^{\prime \prime} \mathrm{S}$ & $174^{\circ} 02^{\prime} 40^{\prime \prime} \mathrm{W}$ & 20 & $6000-0$ yr BP & 3.4 & $\begin{array}{l}\text { Fall } \\
\text { unpublished }\end{array}$ \\
\hline \multicolumn{8}{|c|}{$\begin{array}{l}\text { Cyperaceae (Eleocharis dulcis and Lepironia articulata) marsh surrounded by Poaceae, Stachytarpeta urticifolia, } \\
\text { Ludwigia octovalvis, Erythrina variegata }\end{array}$} \\
\hline $\begin{array}{l}\text { Avai'o'vuna } \\
\text { Swamp }\end{array}$ & Pangaimotu & $18^{\circ} 41^{\prime} 44^{\prime \prime} \mathrm{S}$ & $173^{\circ} 59^{\prime} 02^{\prime \prime} \mathrm{W}$ & 1.5 & $4500-0$ yr BP & 1.5 & Fall 2005 \\
\hline \multicolumn{8}{|c|}{$\begin{array}{l}\text { Coastal forest of Pandanus tectorius, Cocos nucifera and Hernandia nymphaeifolia, Cocos plantation, and Coloca- } \\
\text { sia swamp }\end{array}$} \\
\hline \multicolumn{8}{|c|}{ Ha'apai Island Group } \\
\hline $\begin{array}{l}\text { Lotofoa } \\
\text { Swamp }\end{array}$ & Foa & $19^{\circ} 44^{\prime} 48^{\prime \prime} \mathrm{S}$ & $174^{\circ} 18^{\prime} 27^{\prime \prime} \mathrm{W}$ & 3 & $6700-0$ yr BP & 3.13 & $\begin{array}{l}\text { Flenley et } \\
\text { al. } 1999\end{array}$ \\
\hline \multicolumn{8}{|c|}{ Ludwigia octovalvis, Cyperaceae and Poaceae swamp surrounded by Erythrina variegata } \\
\hline $\begin{array}{l}\text { Finemui } \\
\text { Swamp }\end{array}$ & Ha’afeva & $19^{\circ} 56^{\prime} 45^{\prime \prime} \mathrm{S}$ & $174^{\circ} 42^{\prime} 35^{\prime \prime} \mathrm{W}$ & 6 & $5800-0$ yr BP & 3.33 & $\begin{array}{l}\text { Flenley et } \\
\text { al. } 1999\end{array}$ \\
\hline \multicolumn{8}{|c|}{ Polygonum cf. glabrum swamp with Ludwigia octovalvis, Poaceae, Cyperaceae, Cocos nucifera } \\
\hline \multicolumn{8}{|c|}{ Tongatapu Island Group } \\
\hline $\begin{array}{l}\text { Folaha } \\
\text { Swamp }\end{array}$ & Tongatapu & $21^{\circ} 11^{\prime} \mathrm{S}$ & $175^{\circ} 11^{\prime} \mathrm{W}$ & $0.4-0.9$ & $6900-0$ yr BP & 3.2 & $\begin{array}{l}\text { Ellison } \\
1989\end{array}$ \\
\hline \multicolumn{8}{|c|}{$\begin{array}{l}\text { Rhizophora mangrove at lagoon edge with Bruguiera, Acrostichum aureum, Excoecaria, Hibiscus tiliaceus and } \\
\text { Stenochlaena palustris }\end{array}$} \\
\hline Ano'a'pepe & 'Eua & $21^{\circ} 24^{\prime} 03^{\prime \prime} \mathrm{S}$ & $174^{\circ} 55^{\prime} 05^{\prime \prime} \mathrm{W}$ & 250 & Undated & 0.6 & $\begin{array}{l}\text { Fall } \\
\text { unpublished }\end{array}$ \\
\hline
\end{tabular}

\section{Vava'u Island Group}

Vava'u is the northernmost of the three limestone island groups that make up the Kingdom of Tonga. The main island of 'Uta Vava'u forms the northern edge of an uplifted limestone platform, including several embayments and the brackish water Lake Ano. The limestone platform of Vava'u slopes southward, where its subsidence has produced numerous smaller islands (Dickinson and Burley 2007). Several swamps were examined in Vava'u, including the two discussed here - Ngofe Marsh and Avai'o'vuna Swamp - for their potential to provide palaeoecological data on pre-settlement forests and subsequent vegetation change associated with settlement by Lapita and later cultures (Fall 2005). Avai'o'vuna Swamp is a very small basin about $5 \mathrm{~m} \mathrm{x} 10 \mathrm{~m}$ in size that lies about $1.5 \mathrm{~m}$ above mean sea level on the eastern shore of Pangaimotu Island. The swamp is a sedge wetland surrounded by coastal forest trees, Pandanus tectorius, Hernandia nymphaeifolia and Cocos nucifera, set among more extensive 
Cocos plantations on the island. Colocasia esculenta and Ipomoea batatas are cultivated in wetter soils. Ngofe Marsh is a sedge, grass and reed marsh on the eastern flank of Mount Mo'ungalafa on 'Uta Vava'u, separated from Lake Ano by a low rise. Vegetation on Ngofe Marsh is dominated by Eleocharis dulcis and Lepironia articulata, with grasses, sedges, Stachtarpeta urticifolia, Polygonum dichotomum, and the swamp tree Erythrina variegata at the edge of the marsh (Figure 3).

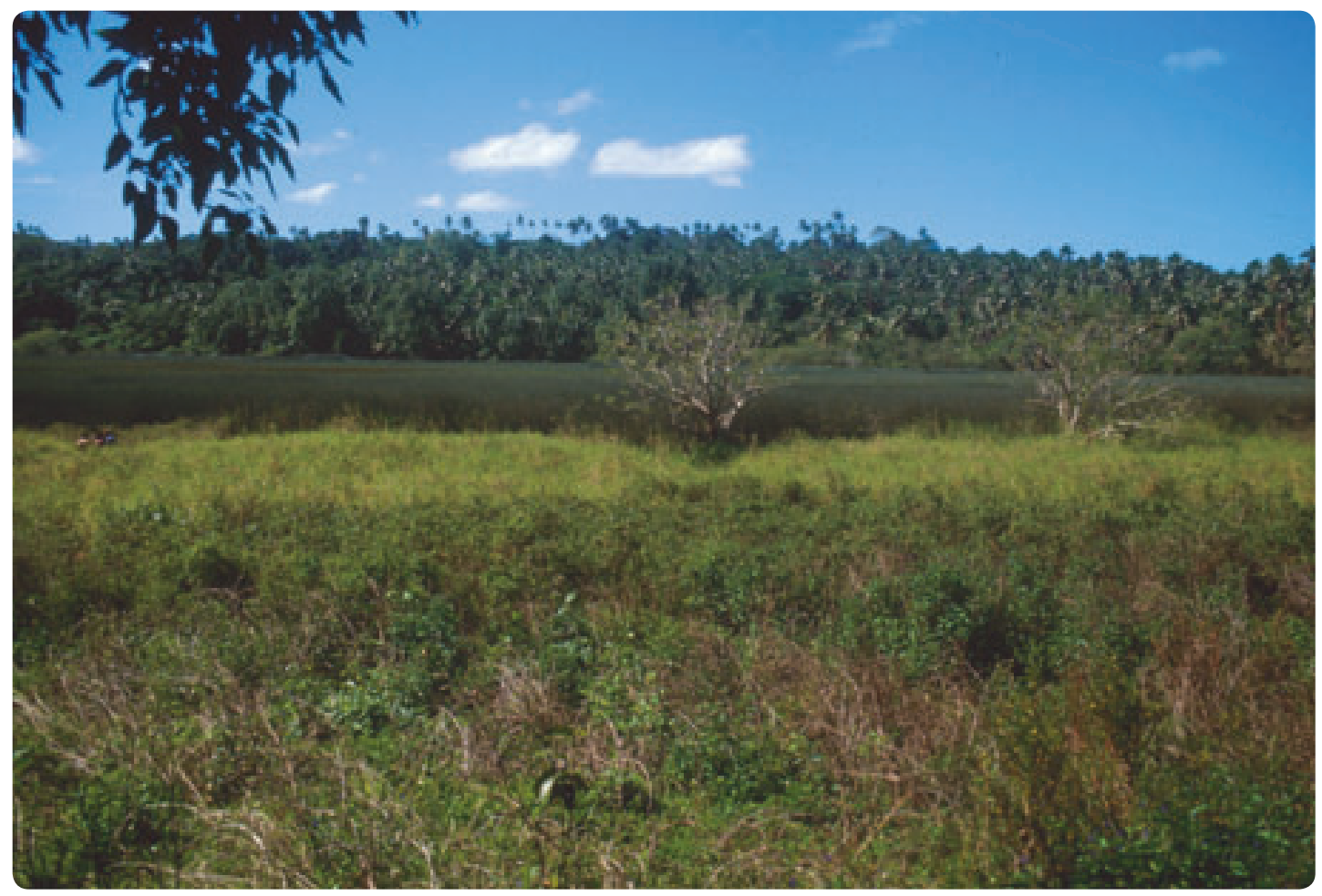

Figure 3. Ngofe Marsh on 'Uta Vava'u, Vava'u island group. Photograph by P. Fall

The coastal wetland Avai'o'vuna Swamp produced a 2 m sediment record, documenting sea-level variation, fire history and vegetation change. During a marine high-stand from 4500 to $2600 \mathrm{yr}$ BP, the swamp was dominated by mangroves, including Rhizophora mangle and Excoecaria, the coastal trees Barringtonia, Pandanus tectorius and Cocos nucifera, and Malvaceae (perhaps Thespesia populnea), and was surrounded by lowland rainforest with Hedycarya, Calophyllum (presumably C. inophyllum), Rhus, Papillionaceae and Alphitonia (Fall 2005). After about $2600 \mathrm{yr} \mathrm{BP}$, sea level dropped and fire, as attested by the appearance of microscopic charcoal in the sediments, became common. The recent vegetation around the swamp is dominated by mangroves (Excoecaria), coastal forest (Pandanus tectorius and Cocos nucifera), successional forest (Macaranga), and open vegetation of sedges, grasses and ferns. Past rainforest dynamics have included shifts to Homalanthus and Macaranga as secondary taxa, with declines in pollen from rainforest trees, including Hedycarya, Calophyllum, Elaeocarpus, Monimiaceae, Neonauclea, Pleiogynium and Papillionaceae (Fall 2005).

Plant taxa more common at Avai'o'vuna Swamp before Polynesian colonisation included Hedycarya, Neonauclea, Guettarda and Solanum (possibly S. amicorum) (Fall 2005). Following Polynesian colonisation, rainforest trees, particularly Hedycarya, Calophyllum, Elaeocarpus and Rhus, declined in abundance. Plants that increased and/or were possibly introduced by Polynesian settlers include cultivated grass (Poaceae $>40-50 \mu \mathrm{m}$ ), Casuarina, Erythrina and Canarium.

Ngofe Marsh produced a record indicating that the basin contained a lake between about 7000 and 3000 yr BP. Associated rainforest taxa included Elaeocarpus, Dysoxylum, Ellatostachys, Flacourtiaceae, Garuga, Hedycarya, Maniltoa, Melastomataceae and Papillionaceae. Microscopic 
charcoal first appears in sediments from about $2800 \mathrm{yr}$ BP, coincident with the arrival of Lapita people on Vavau (Burley and Connaughton 2007). Along with the abundant charcoal, the infilling of the lake and the spread of plants on to the marsh is attested by dramatic increases in Poaceae and Cyperaceae pollen and fern spores after $2800 \mathrm{yr}$ BP. The lowland rainforest surrounding Ngofe Marsh became less diverse after this time, with significant losses in most rainforest trees, accompanied by the notable expansion of Pandanus tectorius and Macaranga. Plant taxa with truncated records at Ngofe Marsh following Polynesian colonisation include Dysoxylum, Garuga, Homalium, Maniltoa, Pleiogynium, Syzygium, Freycentia and one type of Pandanus. Cultivated grass (Poaceae $>40-50 \mu \mathrm{m}$; grains often have a double pore, or rarely a triple pore), Colocasia, Pometia and Erythrina are likely Polynesian introductions.

\section{Ha'apai Island Group}

The middle island group of Ha'apai is made up of a multitude of small low limestone islands and atolls to the east and the two more recent, larger and higher volcanic islands of Kao and Tofua at the western edge. Flenley and others (1999) examined two small swamps in Ha'apai on the islands of Ha'afeva and Foa for their potential to provide palaeoecological information applicable to Lapita and later archaeological sites investigated by Burley and colleagues (Burley 1994; Burley et al. 1999, 2001). The two swamps examined, Finemui (on Ha'afeva) and Lotofoa (on Foa), were most likely former lagoons within the atolls (Flenley et al. 1999). Both basins are surrounded by herbaceous and shrub vegetation. Finemui Swamp is dominated by Polygonum cf. glabrum, with other herbaceous plants, including Ludwigia octovalvis and plants in the Poaceae and Cyperaceae families. Cocos nucifera, Inocarpus fagifer, Morinda citrifolia and Erythrina variegata are marginal trees. Lotofoa Swamp is characterised by Ludwigia octovalvis, plants in the Cyperaceae, Poaceae and Leguminosae families, as well as ferns, Erythrina and other trees.

Basal organics began to accumulate in Finemui Swamp about 5770 yr BP (Flenley et al. 1999). The indigenous or pre-settlement vegetation at Finemui Swamp is interpreted as a brackish or freshwater wetland, which was replaced by a fern and Polygonum swamp, with the coastal trees Hibiscus and Trema (Flenley et al. 1999). Pollen from Elaeocarpus, Trema, Urticaceae/Moraceae and Meliaceae/Sapotaceae is indicative of the surrounding rainforest trees. The record also demonstrates a slight sea-level rise before disturbed sediments that are hypothesised to relate to the Lapita phase. Flenley and others (1999) also associate Lapita occupation with an expansion of Glochidion pollen (interpreted as a possible opening in the forest canopy) and increases in Pandanus, Casuarina and Cocos nucifera pollen, all of which could have been encouraged by planting. Peaks in Cyperaceae and Poaceae pollen and monolete fern spores seen at Finemui Swamp also are associated commonly with forest disturbance on other Polynesian islands (Parkes et al. 1992; Kirch et al. 1995; Kirch 1996; Parkes 1997; Flenley et al. 1999). The modern environment of Finemui Swamp is dominated by Polygonum, Cyperaceae and ferns, with Cocos nucifera and Trema as the most common dryland trees, accompanied by Pandanus and Gardenia, Elaeocarpaceae and Macaranga. Herbaceous plants include Poaceae and weedy taxa. Probable recently introduced species include Gardenia, Stachytarpheta, Ipomoea (Ipomoea cf. batatas) and Solanum (S. cf. nigrum) (Flenley et al. 1999).

Similarly, Flenley and others (1999) interpret the vegetation at Lotofoa Swamp before Polynesian settlement as a fern wetland surrounded by a coastal forest of Pandanus and Hibiscus, as well as Podocarpus, Mallotus and Planchonella trees. Lotofoa Swamp became an Excoecaria swamp during Polynesian settlement, and provides evidence of Cocos pollen. The modern vegetation at the swamp is represented by Cyperaceae and Poaceae pollen and fern spores. Dryland vegetation surrounding Lotofoa Swamp has been deforested, perhaps followed by the planting of Cocos, Gardenia, Trema and Triumfetta. Probable Polynesian introductions to 
Ha'apai include Ipomoea cf. batatas, Cocos and Casuarina, accompanied by an expansion of Pandanus (Flenley et al. 1999).

\section{Tongatapu Island Group}

Ano'a'pepe, on the island of 'Eua, is a small lake about $1.5 \mathrm{~m}$ deep surrounded by plants in the Cyperaceae and Poaceae families. The forest surrounding the lake is dominated by Calophyllum neo-ebudicum, Dysoxylum tongense and Ellatostachys falcata, as is typical of upland rainforests on 'Eua (Drake et al. 1996). Although the rainforest immediately surrounding the lake is undisturbed, plantations of Pinus caribaea grow nearby. Approximately $1 \mathrm{~m}$ of organic gyttja was recovered from Ano'a'pepe in 1998; pollen preservation was good in the uppermost $50 \mathrm{~cm}$ of the core (Fall unpublished). The presence of microscopic charcoal, the abundance of Poaceae (including grains $>40-50 \mu \mathrm{m}$; see discussion below), Cyperaceae pollen and fern spores, and the presence of pollen from introduced trees (e.g. Pinus and Mimosa in the upper few centimetres) suggest a relatively recent age (at least post-Polynesian) for this core.

Ellison (1989) collected a series of sediment cores from Fanga 'Uta Lagoon on Tongatapu to investigate sea-level change. A basal age of about $6900 \mathrm{yr}$ BP demonstrates that the lagoon was a brackish marsh dominated by Cyperaceae and Acrostichum aureum, which lay about $1 \mathrm{~m}$ above modern mean sea level. This interpretation agrees with Dickinson and Burley's (2007:247) inference of a marine high-stand that peaked about $5000 \mathrm{yr} \mathrm{BP}$, and a subsequent draw-down of sea level beginning about $3000 \mathrm{yr}$ BP. A late Holocene sea-level drop is represented by a mangrove forest designated by pollen from Hibiscus, Bruguiera, Excoecaria and Stenochlaena palustris spores. The uppermost peat samples contain pollen from the introduced tree Psidium guajava.

\section{Introduced plants}

A number of tree, crop and ornamental plants was introduced to Tonga and cultivated by its Polynesian and European inhabitants. Analysis of pollen from the small marshes and swamps on Tonga, described above, provides a unique window into the human ecology of these islands. Based on ethnographic information and early botanical collections, Whistler (1991) provides a valuable compendium of the plants of Tonga, their names and their uses. Drawing on Whistler's (1991) observations of cultivated or aboriginal introductions, I discuss useful tree and herbaceous cultigens for which we have a palynological record, as well as inadvertent introductions. Interestingly, many taxa known to be European introductions do not appear in pollen records, perhaps reflecting a combination of palynological invisibility and restricted distributions. Although a wide range of taxa introduced by Polynesians is signalled palynologically, other Polynesian introductions, such as Colocasia escuelenta and Ipomoea batatas, may be invisible for the same reasons (Haberle 1995; Haberle and Atkins 2005). The subsequent discussions note the species most likely responsible for each pollen type represented in the subfossil record (pollen identification often is limited to genus, type or family), listed by scientific name with authority, followed by the Tongan and English names (in parentheses), as available (after Whistler 1991).

\section{Pollen evidence for Polynesian introductions}

Canarium harveyi var. harveyi is indigenous to Tonga, where it is found today mostly as a cultivated tree in villages. Its edible almond-like seeds, timber and sap are used by Tongans (Whistler 1991). Canarium pollen appeared in small amounts in both Ngofe Marsh and Avai'o'vuna Swamp before Lapita settlement, but is more abundant and consistent in the 
Table 3. Plant taxa that first appear (FAD) in sediment cores from Tonga or show an increase in pollen in the uppermost sediments after Lapita (Polynesian) colonisation

\begin{tabular}{|c|c|c|c|c|}
\hline Botanical species & Island & Core & Evidence & Reference \\
\hline \multirow{3}{*}{$\begin{array}{l}\text { Canarium harveyi } \\
\text { Leenh. }\end{array}$} & Pangaimotu, Vava'u & Avai'o'vuna Swamp & Pollen increase c. $2600 \mathrm{BP}$ & Fall 2005 \\
\hline & 'Uta Vava'u, Vava'u & Ngofe Marsh & Pollen increase c. $2600 \mathrm{BP}$ & Fall unpublished \\
\hline & 'Eua & Ano'a’pepe & FAD pollen (recent) & Fall unpublished \\
\hline \multirow{3}{*}{$\begin{array}{l}\text { Casuarina } \\
\text { equisetifolia L. }\end{array}$} & Pangaimotu, Vava'u & Avai'o'vuna Swamp & FAD pollen c. $2600 \mathrm{BP}$ & Fall 2005 \\
\hline & Ha’afeva, Ha’apai & Finemui Swamp & Pollen increase c. 2000 BP & Flenley et al. 1999 \\
\hline & 'Eua & Ano'a’pepe & FAD pollen (recent) & Fall unpublished \\
\hline \multirow{4}{*}{ Cocos nucifera $\mathrm{L}$. } & Pangaimotu, Vava’u & Avai'o'vuna Swamp & Pollen increase c. $1000 \mathrm{BP}$ & Fall 2005 \\
\hline & 'Uta Vava'u, Vava'u & Ngofe Marsh & $\begin{array}{l}\text { Pollen increase after } 4000 \\
\text { BP }\end{array}$ & Fall unpublished \\
\hline & Ha’afeva, Ha’apai & Finemui Swamp & $\begin{array}{l}\text { Pollen increase after } 1800 \\
\text { BP }\end{array}$ & Flenley et al. 1999 \\
\hline & Foa, Ha’apai & Lotofoa Swamp & FAD pollen c. $2900 \mathrm{BP}$ & Flenley et al. 1999 \\
\hline \multirow{3}{*}{$\begin{array}{l}\text { Colocasia esculenta } \\
\text { (L.) Schott. }\end{array}$} & Pangaimotu, Vava’u & Avai'o'vuna Swamp & FAD pollen c. $2600 \mathrm{BP}$ & Fall 2005 \\
\hline & 'Uta Vava'u, Vava'u & Ngofe Marsh & FAD pollen c. $2000 \mathrm{BP}$ & Fall unpublished \\
\hline & 'Eua & Ano'a’pepe & FAD pollen (unknown age) & Fall unpublished \\
\hline \multirow{2}{*}{$\begin{array}{l}\text { Cordyline fruticosa } \\
\text { (L.) A. Chev. }\end{array}$} & Pangaimotu, Vava’u & Avai'o'vuna Swamp & FAD pollen c. $2600 \mathrm{BP}$ & Fall 2005 \\
\hline & 'Uta Vava'u, Vava'u & Ngofe Marsh & FAD pollen c. $2200 \mathrm{BP}$ & Fall unpublished \\
\hline \multirow[t]{2}{*}{ Erythrina variegata $\mathrm{L}}$. & Pangaimotu, Vava’u & Avai'o’vuna Swamp & FAD pollen c. $1500 \mathrm{BP}$ & Fall 2005 \\
\hline & 'Uta Vava’u, Vava’u & Ngofe Marsh & FAD pollen c. $2400 \mathrm{BP}$ & Fall unpublished \\
\hline \multirow{2}{*}{$\begin{array}{l}\text { Gardenia tannaensis } \\
\text { Guillaumin }\end{array}$} & Pangaimotu, Vava'u & Avai'o'vuna Swamp & FAD pollen c. $2200 \mathrm{BP}$ & Fall 2005 \\
\hline & Ha’afeva, Ha’apai & Finemui Swamp & Pollen increase c. 2200 BP & Flenley et al. 1999 \\
\hline \multirow{2}{*}{$\begin{array}{l}\text { Ludwigia octovalvis } \\
\text { (Jacq.) Raven }\end{array}$} & Foa, Ha’apai & Lotofoa Swamp & FAD pollen c. $2500 \mathrm{BP}$ & Flenley et al. 1999 \\
\hline & 'Uta Vava’u, Vava’u & Ngofe Marsh & $\begin{array}{l}\text { Single Onagraceae grain c. } \\
2000 \mathrm{BP}\end{array}$ & Fall unpublished \\
\hline \multirow{3}{*}{$\begin{array}{l}\text { Pandanas tectorius } \\
\text { Parkinson }\end{array}$} & Pangaimotu, Vava’u & Avai'o'vuna Swamp & Pollen increase c. 1500 BP & Fall 2005 \\
\hline & 'Uta Vava’u, Vava'u & Ngofe Marsh & Pollen increase c. $2400 \mathrm{BP}$ & Fall unpublished \\
\hline & Ha'afeva, Ha’apai & Finemui Swamp & Pollen increase c. $2900 \mathrm{BP}$ & Flenley et al. 1999 \\
\hline \multirow{3}{*}{$\begin{array}{l}\text { Poaceae (grains } \\
>40 \mu \mathrm{m})\end{array}$} & Pangaimotu, Vava'u & Avai'o'vuna Swamp & FAD pollen c. $2600 \mathrm{BP}$ & Fall 2005 \\
\hline & 'Uta Vava’u, Vava'u & Ngofe Marsh & FAD pollen c. $2800 \mathrm{BP}$ & Fall unpublished \\
\hline & 'Eua & Ano'a'pepe & FAD pollen (unknown age) & Fall unpublished \\
\hline \multirow[t]{2}{*}{ Poaceae } & Foa, Ha’apai & Lotofoa Swamp & Pollen increase c. $3100 \mathrm{BP}$ & $\begin{array}{l}\text { Flenley et al. } \\
1999\end{array}$ \\
\hline & Ha’afeva, Ha’apai & Finemui Swamp & Pollen increase c. 900 BP & Flenley et al. 1999 \\
\hline \multirow{2}{*}{$\begin{array}{l}\text { Polygonum } \\
\text { dichotomum } \mathrm{Bl} \text {. Bijar }\end{array}$} & Ha'afeva, Ha'apai & Finemui Swamp & Pollen increase c. $1600 \mathrm{BP}$ & Flenley et al. 1999 \\
\hline & 'Uta Vava’u, Vava'u & Ngofe Marsh & Pollen increase c. $1000 \mathrm{BP}$ & Fall unpublished \\
\hline $\begin{array}{l}\text { Pometia pinnata J.R. } \\
\& \text { G. Forst. }\end{array}$ & 'Uta Vava’u, Vava’u & Ngofe Marsh & FAD pollen c. $2500 \mathrm{BP}$ & Fall unpublished \\
\hline $\begin{array}{l}\text { Stenochlaena palustris } \\
\text { (Burm.) Beddome }\end{array}$ & Foa, Ha’apai & Lotofoa Swamp & FAD pollen c. $1100 \mathrm{BP}$ & Flenley et al. 1999 \\
\hline
\end{tabular}

Note: All ages estimated from sedimentation rates based on radiocarbon ages from each core. Ngofe Marsh and Avai'o'vuna Swamp each have two ${ }^{14} \mathrm{C}$ ages; Finemui and Lotofoa Swamps have one ${ }^{14} \mathrm{C}$ age each. 
records following Polynesian settlement. These suggest aboriginal cultivation of this tree, leading to its modern distribution as a cultivated species in villages (Table 3).

Casuarina equisetifolia is suggested to have been either an indigenous tree or an aboriginal introduction to Tonga (Whistler 1991). Haberle (2007) documents the planting of Casuarina equisetifolia in New Guinea to aid nitrogen-fixing in the soil, noting that increased Casuarina pollen indicates arboriculture. Whistler (1991:125) notes that Casuarina often is cultivated in Tonga and that its hard wood is used for posts, tapa mallets, war clubs and other tools. Pollen evidence documents Casuarina trees in Tonga before human occupation of the islands, but its abundance and distribution on the islands may have been expanded by Polynesians. Pollen records from Ha’apai (Finemui Swamp) (Flenley et al. 1999) and Vava'u (Ngofe Marsh) (Fall unpublished) suggest that this tree was maintained and probably planted during Lapita occupation. Casuarina pollen first appears in Avai'o'vuna Swamp on Pangaimotu Island after Polynesian arrival (Fall 2005). Similarly, Casuarina pollen is found in pre-aboriginal sediments on Rapa and Rapanui, then shows a marked increase about 1000 cal. BP (Prebble 2008; Prebble and Wilmshurst 2009).

Cocos nucifera is thought to be an aboriginal introduction to Tonga, where it is cultivated widely in plantations throughout the islands. Coconut provides a liquid that can be substituted for water during periods of drought, meat that can be eaten, and oil that can be made from the nut. Virtually every part of the plant has a use, including its shell, leaves and roots (Whistler 1991:94). While Cocos nucifera-type pollen is found in sediments from Tonga prior to colonisation, one record in Ha'apai (Lotofoa Swamp) shows the first Cocos pollen coincident with the arrival of Lapita people. Other records from Ha'apai (Finemui Swamp) and Vava'u (Ngofe Marsh and Avai'o'vuna Swamp) document its expansion following Lapita settlement. Similarly, palaeoenvironmental records from Vanuatu (Spriggs 1984), Mo'orea (Parkes 1997) and the Cook Islands (Ellison 1994; Kirch and Ellison 1994) provide evidence for Cocos nucifera on Pacific islands prior to human settlement. Cocos palms may have been introduced by early Polynesian settlers on the Hawaiian Islands (Athens and Ward 1997) and by European immigrants to French Polynesia (Prebble 2008; Prebble and Wilmshurst 2009).

Colocasia esculenta was brought to Tonga by Polynesian settlers. This starchy cultigen is a staple crop and its many varieties introduced by aboriginal and more recent populations are cultivated widely (Whistler 1991:117). In Tonga, the earliest Colocasia pollen is found in Avai'o'vuna Swamp (at about 2600 yr BP), Ngofe Marsh (at about $1800 \mathrm{yr}$ BP), and Ano'a'pepe on the island of 'Eua (in the upper sediments). Although Colocasia pollen is not preserved in some sedimentary basins (Haberle 1995), it has been associated with Polynesian settlement and cultivation in other parts of Polynesia, specifically Hawai'i (Athens and Ward 1993, 1997) and French Polynesia (Kennett et al. 2006; Prebble 2008; Prebble and Wilmshurst 2009).

Cordyline fruticosa is an aboriginal introduction to Tonga. The root of Cordyline fruticosa was consumed as food in the past; the plant is used today as an ornamental and its leaves are harvested for cooking or medicinal uses (Whistler 1991:111). The first appearance of Cordyline pollen at Ngofe Marsh at about $2200 \mathrm{yr}$ BP and at Avai'o'vuna Swamp about 2600 yr BP corroborates the interpretation of Cordyline fruticosa as a Polynesian introduction to Vava'u. Prebble (2008) also found Cordyline pollen associated with aboriginal colonisation in sedimentary records from subtropical Polynesian islands.

Erythrina variegata, although thought to be an indigenous tree, today is found mostly in cultivation. Erythrina fusca, which grows in swamps and marshes on Tonga, may have been introduced to Tonga by Polynesians, perhaps from Fiji, as its Tongan name (ngatae fisi, Fijian coral tree) suggests (Whistler 1991:38-39). Erythrina trees are commonly found at the edges of wetlands like Ngofe Marsh on Vava'u and at Finemui and Lotofoa swamps on Haapai. Erythrina pollen appears for the first time in Ngofe Marsh about $2400 \mathrm{yr}$ BP and in Avai'o'vuna Swamp about 1500 yr BP, after Lapita colonisation of Vava'u, supporting 
Whistler's suggestion that one of the species of Erythrina is a Polynesian introduction, or that Erythrina became more prominent in the palynological record.

Gardenia taitensis is an indigenous littoral species in Fiji, which grows on Tonga (Smith 1988). Gardenia tannaensis is a tree that is cultivated and naturalised on Niuatoputapu and was probably introduced from Tanna, Vanuatu, where it is indigenous (Whistler 1991:111). Gardenia augusta is a European introduction (Whistler 1991:112). Gardenia pollen is found in pre-Lapita sediments in both Lotofoa and Finemui swamps (Flenley et al. 1999), strongly supporting Smith's (1988) idea that Gardenia taitensis is indigenous to Tonga. Gardenia pollen also is present in Lapita and post-Lapita-age sediments at both Finemui and Lotofoa swamps. Increased frequencies of Gardenia pollen in Lapita and particularly in post-Lapita sediments at Finemui Swamp (Flenley et al. 1999), and its first appearance in Avai'o'vuna Swamp at about $2200 \mathrm{yr}$ BP (Fall 2005), lend support to the possibility of Polynesian planting or encouragement of Gardenia plants, or the increased palynological visibility of Gardenia on Tongan Islands.

Ipomoea batatas is an aboriginal introduction to Tonga, commonly found in cultivation today (Whistler 1991). Pollen identified as Ipomoea cf. batatas is noted in Finemui Swamp at a depth of 0.15-0.24 m (Flenley et al. 1999) and as two grains from Avai'o'vuna Swamp at 0 $\mathrm{m}$ and $0.24 \mathrm{~m}$ below the surface of the swamp (Fall 2005). This pollen type is very distinctive (Flenley et al. 1999), but normally is not preserved in sediments (Haberle and Atkins 2005). At Avai'o'vuna Swamp the presence of sweet-potato pollen fits the criteria outlined by Haberle and Atkins (2005) for its association with Casuarina equisetifolia silviculture, signalled by the first appearance of Casuarina pollen in this little swamp.

Ludwigia octovalvis, a pan-tropical species, is a native of tropical America and an introduction to the Pacific islands, where it is common in wetlands and is associated with Colocasia cultivation (Whistler 1995:113). Ludwigia octovalvis currently dominates the vegetation in some swamps and wetlands in Tonga. Of particular interest here, it grows at the edge of Ngofe Marsh in Vava'u (Fall unpublished) and in both of the swamps investigated by Flenley and colleagues (1999) on Ha'apai, where it dominates the vegetation in Lotofoa Swamp. Although Whistler (1995) suggests that Ludwigia octovalvis is a European introduction, the evidence presented below suggests it may have been introduced inadvertently by Polynesians. Ludwigia pollen is found associated with Colocasia pollen in Polynesian-age deposits in a sediment core from Hawaii (Athens and Ward 1997). Ludwigia pollen and seeds document this taxon as an inadvertent Polynesian introduction to Rapa (Prebble 2008). In Tonga, Ludwigia pollen first appears in Lapita-age sediments at Lotofoa Swamp (Zone LF 4) (Flenley et al. 1999). At Ngofe Marsh a single Onagraceae (cf. Ludwigia) pollen grain is found in association with Colocasia pollen in sediments dated to about $2000 \mathrm{yr}$ BP. Ludwigia octovalvis is a common weed associated with Colocasia escuelenta fields throughout the Pacific (Kirch 1994). The discovery of Ludwigia pollen in Lapita-age ponds on Ha'apai and Vava'u suggests that Ludwigia was a Polynesian introduction to Tonga.

Pandanus tectorius is an indigenous and cultivated tree in Tonga. Whistler (1991:70-76) describes the many varieties and uses for the indigenous Pandanus tectorius, as well as for the Polynesian introduction Pandanus whitmeeanus and for Pandanus veitchii, which probably was introduced from Hawai'i. Pandanus tectorius-type pollen is present in Tonga in sediments deposited before colonisation by Polynesians, as it is on other Polynesian islands (Prebble 2008). However, Pandaus tectorius-type pollen is more abundant in Avai'o'vuna Swamp, Ngofe Marsh and Finemui Swamp after Lapita colonisation, supporting the suggestion that people may have planted Pandanus tectorius and encouraged its growth throughout the Tongan Islands.

Phyllanthus amicorum, although not mentioned in Whistler (1991), is an endemic tree or small shrub that grows today on 'Eua (Drake et al. 1996) and Vava'u (Steadman et al. 1999). While Phyllanthus amicorum or another species of Phyllanthus may have grown in 
Tonga before human colonisation, Phyllanthus-type pollen makes its initial appearance in Avai'o'vuna Swamp in the upper sediments deposited in the past 300 years (Fall 2005).

Poaceae pollen increases in all Tongan sediment cores coincident with Lapita settlement and burning. Saccharum officinarum, Schizostachyum glaucifolium and Miscanthus floridus are recognised as Polynesian introductions to Tonga (Whistler 1991). Miscanthus floridus was used for arrow shafts, pipes or construction (Whistler 1991:50). The two cane species Saccharum officinarum and Schizostachyum glaucifolium were cultivated grasses. The sweet stalks of Saccharum officinarum provided food and its leaves were used for thatch (Whistler 1991:1245). Schizostachyum glaucifolium occasionally was cultivated or became naturalised, providing materials for poles, vessels, musical instruments and construction (Whistler 1991:57).

While small amounts of Poaceae pollen (1-2\%) are found in Ngofe Marsh before Polynesian arrival, increases in Poaceae pollen (up to $270 \%$ calculated outside the terrestrial pollen sum), Poaceae pollen $>40-50 \mu \mathrm{m}$ (up to $85 \%$ calculated outside the terrestrial pollen sum), and Poaceae pollen with two to three pores (up to $45 \%$ calculated outside the terrestrial pollen sum) jump dramatically with the onset of burning of the marsh (denoted by the presence of microscopic charcoal) and the arrival of Polynesian colonists (Figure 4). Similarly, Poaceae pollen, particularly grains $>40-50 \mu \mathrm{m}$, becomes more abundant in Avai'o'vuna Swamp about $2600 \mathrm{yr}$ BP, and again coincident with the onset of microscopic charcoal deposition (Fall 2005). Ano'a' pepe on 'Eua contains Poaceae pollen $>40-50 \mu \mathrm{m}$, some Poaceae with multipores, and microscopic charcoal throughout the $1 \mathrm{~m}$ core.

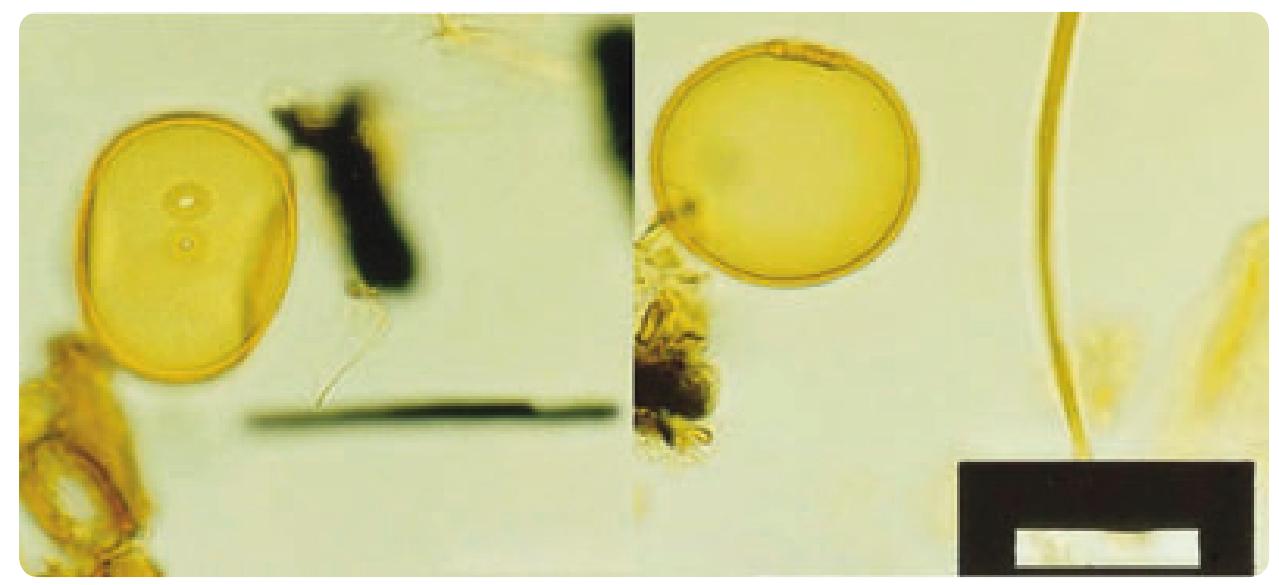

Figure 4. Poaceae pollen from Ngofe Marsh (scale bar $=50 \mu \mathrm{m}$ [black rectangle]). Photo by P. Fall

The possibility that these Poaceae pollen grains from the Vava'u and 'Eua cores represent a cultivated or hybridised grass is strengthened by their larger size and multiple pores. Erdtman (1969) notes that hybridised cultigens in the Poaceae family may be diporate, multiporate or inapertuate (e.g. Tricale, a hybrid of Triticum and Secale, often has two or more pores). Saccharum officinarum hybridises with Saccharum spontaneum, as well as other genera, including Erianthus, Miscanthus, Narenga and Sclerostachys (Aitkens et al. 2007), perhaps leading to the production of these subfossil hybrid pollen grains. Thus, one of the cane or reed grasses brought by Polynesians to Tonga may have been cultivated on Vava'u and 'Eua.

Polygonum dichotomum (synonym Polygonum glabrum) has been suggested as a Polynesian introduction to Tonga (Smith 1981). This common wetland plant (Whistler 1992b) currently grows in Tongan swamps, including Finemui Swamp on Ha'afeva (Flenley et al. 1999), and dominates the marsh vegetation at Vasi Vasi Swamp on Hunga Island, Vava'u (Fall unpublished). Polygonum pollen first appears at Ngofe Marsh about $4000 \mathrm{yr}$ BP, prior to Polynesian settlement, but is much more common on the marsh after $1000 \mathrm{yr}$ BP. Polygonumtype pollen appears throughout the record at Avai'o'vuna Swamp. Although Polygonum pollen 
is found in cores from Lotofoa and Finemui swamps on Ha'apai before Lapita colonisation, Polygonum pollen increases in Lapita and subsequent sediments at Finemui Swamp (Flenley et al. 1999).

Pometia pinnata is a large Polynesian introduced tree common in villages and plantations throughout the islands. Fruits of Pometia pinnata are similar to litchi in taste and appearance, and are highly valued by Tongans; its wood is used for timber, tapa pounders and other wooden tools (Whistler 1991:121). Pometia pollen first appears in Ngofe Marsh at $2500 \mathrm{yr}$ BP, just after the arrival of Polynesians, suggesting that early colonists most likely brought this tree.

\section{Pollen evidence for European introductions}

Alternanthera sessilis is a European introduction that is used occasionally as an ornamental around houses (Whistler 1991:70). Alternanthera pollen appears in the uppermost sediments from Avai'o'vuna Swamp, Vava'u, attesting to its European introduction (Fall 2005) (Table 4).

Mimosa pudica is an introduced weedy shrub or small tree found in disturbed habitats (Whistler 1991:85). Mimosa pollen is quite abundant in a short core collected from the mudwater interface at Ano'a'pepe, the small lake in the upland rainforest, attesting to the recent introduction of Mimosa pudica to 'Eua.

Pinus caribaea was introduced to 'Eua, where today it is cultivated in plantations (Whistler 1991:100). Interestingly, although pine species are notoriously prolific pollen producers, and Pinus caribaea plantations grow within a few hundred metres of Ano'a'pepe, only three Pinus pollen grains have been recovered from a single sample collected at the surface $(0 \mathrm{~cm})$ of the lake. Pinus pollen is absent from both Avai'o'vuna Swamp and Ngofe Marsh on Vava'u. However, Flenley and others (1999) found small amounts of Pinaceae pollen in the two cores collected on Haapai, suggesting long-distance transport to these islands.

Psidium guajava is an introduced fruit tree which has become naturalised in pastures and disturbed areas (Whistler 1991:60). Psidium guajava is widespread in Tonga as a cultivated tree and as an adventive species. Psidium pollen appears in the upper peats at Folaha Swamp in Fanga 'Uta Lagoon, Tongatapu, dating to the historic period (50-150 yr BP) (Ellison 1989).

Stachytarpeta urticifolia is a weed introduced recently to Tonga (Whistler 1991:46). Stachytarpeta urticifolia grows in disturbed soils around swamps and is particularly common on the edge of Ngofe Marsh. Stachytarpeta pollen appears in the most recent sediments from Finemui Swamp on Ha'afeva, Haapai, in Zone FM 5 (Flenley et al. 1999).

Stenochlaena palustris, an epiphytic fern, grows on Hibiscus tiliaceous plants in the Rhizophora mangrove at the edge of Folaha Swamp in Fanga 'Uta Lagoon on Tongatapu (Ellison 1989). Whistler (1991:102) notes that it is relatively uncommon in most forests in Tonga. Stenochlaena spores were found in Zone LF5, the most recent sediments in the core from Lotofoa Swamp on Foa, Ha'apai (Flenley et al. 1999). Flenley et al. (1999) suggest that Stenochlaena palustris was introduced from Southeast Asia, where it is common today, became abundant on Ha'afeva Island, and then was extirpated.

\section{Summary}

Dramatic changes follow the settlement and modification of tropical Pacific Island ecosystems by human populations (Hope et al. 1999). The creation of anthropogenic landscapes in Oceania extended from New Guinea eastward with the Lapita culture, and became widespread throughout the Pacific islands (Kirch et al. 1995; Athens et al. 1996; Denham et al. 2003; Kennedy and Clarke 2004; Fairbairn 2005). Vegetation in the Kingdom of Tonga derives from long-distance dispersal (Carlquist 1967, 1974), transport by birds and bats (Rainey et al. 
Table 4. Plant taxa that first appear (FAD) in sediment cores from Tonga or show an increase in pollen in the uppermost sediments after European colonisation

\begin{tabular}{|c|c|c|c|c|}
\hline Botanical Species & Island & Core & Evidence & Reference \\
\hline $\begin{array}{l}\text { Alternanthera sessilis R.Br. } \\
\text { ex DC }\end{array}$ & Pangaimotu, Vava'u & Avai'o'vuna Swamp & $\begin{array}{l}\text { FAD pollen c. } 300- \\
0 \mathrm{BP}\end{array}$ & Fall 2005 \\
\hline \multirow[t]{2}{*}{ Ipomoea batatas $\mathrm{L}$. } & Ha’afeva, Ha’apai & Finemui Swamp & FAD pollen historic & Flenley et al. 1999 \\
\hline & Pangaimotu, Vava'u & Avai'o'vuna Swamp & $\begin{array}{l}\text { FAD pollen c. } 300- \\
0 \mathrm{BP}\end{array}$ & Fall 2005 \\
\hline Mimosa pudica L. & Eua & Ano'a'pepe & FAD pollen $0 \mathrm{BP}$ & Fall unpublished \\
\hline $\begin{array}{l}\text { Phyllanthus amicorum } \\
\text { G.L. Webster }\end{array}$ & Pangaimotu, Vava’u & Avai'o'vuna Swamp & $\begin{array}{l}\text { FAD pollen c. } 300- \\
0 \mathrm{BP}\end{array}$ & Fall 2005 \\
\hline Pinus caribaea Morelet & 'Eua & Ano'a’pepe & FAD pollen $0 \mathrm{BP}$ & Fall unpublished \\
\hline Psidium guajava L. & Tongatapu & Folaha Swamp & $\begin{array}{l}\text { FAD pollen historic } \\
(50-150 \mathrm{yr} \mathrm{BP})\end{array}$ & Ellison 1989 \\
\hline $\begin{array}{l}\text { Stachytarpeta urticifolia } \\
\text { (Salisb.) Sims }\end{array}$ & Ha’afeva, Ha’apai & Finemui Swamp & FAD pollen historic & Flenley et al. 1999 \\
\hline
\end{tabular}

Note: All ages estimated from sedimentation rates based on radiocarbon ages from each core. Ngofe Marsh, Avai'o'vuna and Folaha swamps each have two ${ }^{14} \mathrm{C}$ ages; Finemui and Lotofoa swamps have one ${ }^{14} \mathrm{C}$ age each.

1995; Banack 1998) and human introduction and cultivation (Fall et al. 2007). Palynological evidence for Polynesian and later European plant introductions to Tonga comes from Holocene age sediment cores collected from Vava’u (Fall 2005), Ha’apai (Flenley et al. 1999), Tongatapu (Ellison 1989) and 'Eua (Fall unpublished).

Plants introduced commonly by Lapita colonists include both trees and herbaceous cultigens. In addition, indigenous plants may have been planted and cultivated by Polynesian settlers, allowing the expansion of their native habitats. Plants that were cultivated or whose ranges were expanded by Polynesians in Tonga are represented by pollen from the following tree species - Canarium harveyi, Casuarina equisetifolia, Cocos nucifera, Erythrina variegata, Pandanus tectorius, and Pometia pinnata. Woody shrubs introduced or cultivated by Polynesian settlers include Cordyline fruticosa and Gardenia. Herbaceous taxa introduced or expanded by early colonists consist of Colocasia esculenta, Ludwigia octovalvis, Polygonum, and a cultivated grass species. Pollen deposited in the past few hundred years provides evidence for European cultigens or inadvertent introductions. Pollen from tree species includes the planted Pinus caribaea found in plantations on 'Eua and the naturalised weedy species Mimosa pudica and Psidium guajava, found in very recent-age deposits. Historic-age deposits also contain pollen produced by herbaceous or shrubby vegetation, including Alternanthera, Ipomoea cf. batatas, Phyllanthus and Stachytarpeta, as well as Stenochlaena spores.

Pollen data provide a window to understanding many of the changes that have moulded the Tongan landscape. Polynesian colonists significantly modified their environment through the burning and clearing of indigenous rainforests, making way for cultivated root crops, grasses and ferns. These early settlers also brought a number of woody shrubs and useful tree species, and expanded their ranges, thereby encouraging the creation of anthropogenic forests, as well as open landscapes. European settlement of Tonga further added to the number of cultivated plants, promoted forest clearing and introduced new species, particularly weedy or unintentionally introduced plants.

\section{Acknowledgements}

This research was funded by a research grant from the National Geographic Society and was conducted with the permission of the government of the Kingdom of Tonga. My research into the history of tropical Pacific rainforests on the islands of Tonga was enhanced greatly during 
a sabbatical leave in 1998 spent as a Research Fellow in the Department of Archaeology and Natural History, Research School of Pacific and Asian Studies, at the Australian National University, at the invitation of Geoff Hope. The support and camaraderie extended by Geoff Hope, Janelle Stevenson, Simon Haberle, Sophie Bickford, Mike Macphail, Gillian Atkins and Dominique O'Dea at the ANU were invaluable. This paper was modified from a presentation given in Canberra for a workshop organised by Mat Prebble and Geoff Hope, entitled 'A multidisciplinary workshop for defining plant extinctions from island Oceania and Australia', October 11-13, 2006. Steve Falconer and two anonymous reviewers provided valuable comments.

\section{References}

Aitkens, K., J. Li, L. Wang, C. Qing, Y. H. Fan and P. Jackson 2007. Characterization of intergeneric hybrids of Erianthus rockii and Saccharum using molecular markers. Genetic Resources and Crop Evolution 54:1395-1405.

Athens, J.S. and J.V. Ward 1993. Environmental change and prehistoric Polynesian settlement in Hawai' i. Asian Perspectives 32:205-223.

Athens, J.S. and J.V. Ward 1997. The Maunawili core: prehistoric inland expansion of settlement and agriculture, O'ahu, Hawai' i. Hawaiian Archaeology 6:37-51.

Athens, J.S., J.V. Ward and G.M. Murakami 1996. Development of an agroforest on a Micronesian high island: Prehistoric Kosraean agriculture. Antiquity 70:834-46.

Banack, S.A. 1998. Diet selection and resource use by flying foxes (Genus Pteropus). Ecology 79:1949-1967.

Burley, D.V. 1994. Settlement pattern and Tongan prehistory reconsiderations from Ha'apai. Journal of Polynesian Society 103:379-411.

Burley, D.V. 1998. Tongan archaeology and the Tongan past, 2850-150 BP. Journal of World Prehistory 12:337-92.

Burley, D.V., E. Nelson, and R. Shutler, Jr. 1999. A radiocarbon chronology for the Eastern Lapita frontier in Tonga. Archaeology in Oceania 34:59-70.

Burley, D.V. and W.R. Dickinson 2001. Origin and significance of a founding settlement in Polynesia. Proceedings of the National Academy of Sciences 98:11829-11831.

Burley, D.V. and S.P. Connaughton 2007. First Lapita settlement and its chronology in Vava'u, Kingdom of Tonga. Radiocarbon 49:131-137.

Burney, D.A. 1997. Tropical islands as paleoecological laboratories: Gauging the consequences of human arrival. Human Ecology 25:437-457.

Carlquist, S. 1967. The biota of long-distance dispersal. V. Plant dispersal to Pacific Islands. Bulletin of the Torrey Botanical Club 94:129-162.

Carlquist, S. 1974. Island biology. New York: Columbia University Press.

Denham, T.P., S.G. Haberle, C. Lentfer, R. Fullgar, J. Field, M. Therin, N. Porch and B. Winsborough 2003. Origins of agriculture at Kuk Swamp in the highlands of New Guinea. Science 301:189-193.

Dickinson, W.R. 2001. Paleoshoreline record of relative Holocene sea levels on Pacific islands. Earth-Science Reviews 55:191-234.

Dickinson, W.R. 2003. Impact of mid-Holocene hydro-isostatic highstand in regional sea level on habitability of islands in Pacific Oceania. Journal of Coastal Research 19:489-502.

Dickinson, W.R. and D.V. Burley 2007. Geoarchaeology of Tonga: Geotectonic and geomorphic controls. Geoarchaeology 22:229-259. 
Dickinson, W.R., D.V. Burley and R. Shutler, Jr. 1994. Impact of hydro-static Holocene sea-level change on the geological context of island archaeological sites. Geoarchaeology 9:85-11.

Drake, D.R., W.A. Whistler, T.J. Motley and C.T. Imada 1996. Rain forest vegetation of 'Eua Island, Kingdom of Tonga. New Zealand Journal of Botany 34:65-77.

Ellison, J.C. 1989. Pollen analysis of mangrove sediments as a sea-level indicator - assessment from Tongatapu, Tonga. Palaeogeography, Palaeoclimatology, Palaeoecology 74:327-341.

Ellison, J.C. 1994. Paleo-lake and swamp stratigraphic records of Holocene vegetation and sea-level changes, Mangaia, Cook Islands. Pacific Science 48:1-15.

Erdtman, G. 1969. Handbook of palynology: Morphology, taxonomy, ecology. Copenhagen: Munksgaard.

Fall, P.L. 2005. Vegetation change in the coastal-lowland rainforest at Avai'o'vuna Swamp, Vava'u, Kingdom of Tonga. Quaternary Research 64:451-459.

Fall, P.L., T.D. Drezner and J. Franklin 2007. Dispersal ecology of the lowland rain forest in the Vava'u island group, Kingdom of Tonga. New Zealand Journal of Botany 45:393-417.

Fairbairn, A. 2005. An archaeobotanical perspective on Holocene plant-use practices in lowland northern New Guinea. World Archaeology 37:487-502.

Flenley, J.R., C.T. Hannan and M.J. Farelly 1999. Final report on the stratigraphy and palynology of swamps on the islands of Ha' afeva and Foa, Ha'apai, Tonga. Massey University, Geography Programme Miscellaneous Publication Series 99/3, Palmerston, New Zealand.

Franklin, J. 2003. Regeneration and growth of pioneer and shade-tolerant rain forest trees in Tonga. New Zealand Journal of Botany 41:669-684.

Franklin, J., D.R. Drake, L.A. Bolick, D.S. Smith and T.J. Motley 1999. Rain forest composition and patterns of secondary succession in the Vava'u Island group, Tonga. Journal of Vegetation Science 10:51-64.

Franklin, J, D.R. Drake, K.R. McConkey, F. Tonga and L.B. Smith 2004. The effects of Cyclone Waka on the structure of lowland tropical rain forest in Vava'u, Tonga. Journal of Tropical Ecology 20:409-420.

Franklin, J., S.K. Wiser, D.R. Drake, L.E. Burrows and W.R. Sykes 2006. Environment, disturbance history and rain forest composition across the islands of Tonga, Western Polynesia. Journal of Vegetation Science 17:233-244.

Haberle, S.G. 1995. Identification of cultivated Pandanus and Colocasia in pollen records and the implications for the study of early agriculture in New Guinea. Vegetation History and Archaeobotany 4:195-210.

Haberle, S.G. 2007. Prehistoric human impact on rainforest biodiversity in highland New Guinea. Philosophical Transactions of the Royal Society B 362:219-228.

Haberle, S.G. and G. Atkins 2005. Needles in a haystack: Searching for sweet potato (Ipomoea batatas (L.) Lam.) in the fossil pollen record. In C. Ballard, P. Brown, R.M. Bourke and T. Harwood (eds), The sweet potato in Oceania: a reappraisal, pp25-33, Ethnology Monographs 19. Pittsburgh: University of Pittsburgh Press.

Haberle, S.G. and B. David 2004. Climates of change: Human dimensions of Holocene environmental change in low latitudes of the PEPII transect. Quaternary International 118-119:165-179.

Haberle, S.G., G.S. Hope and S. van der Kaars 2001. Biomass burning in Indonesia and Papua New Guinea: Natural and human induced fire events in the fossil record. Palaeogeography, Palaeoclimatology, Palaeoecology 171:259-268.

Hope, G.S. 2001. Quaternary change and the historical biogeography of Pacific islands. In A. Keast and S.E. Miller (eds), The origin and evolution of Pacific Island biotas, New Guinea to Eastern Polynesia: Patterns and processes, pp165-190. Amsterdam: Academic Publishing. 
Hope, G.S., D. O'Dea and W. Southern 1999. Holocene vegetation histories in the Western Pacific-alternative records of human impact. In I. Lilley and J.-C. Galipaud (eds) The Pacific from 5000 to 2000 BP. Colonisation and Transformations. Paris: Orstom Publishing.

Hope, G.S. and J. Pask 1998. Tropical vegetational change in the late Pleistocene of New Caledonia. Palaeogeography, Palaeoclimatology, Palaeoecology. 142:1-21.

Kennedy, J. and W. Clarke 2004. Cultivated landscapes of the southwest Pacific. Resource Management in Asia-Pacific Working Paper No. 50. Canberra: Resource Management in Asia-Pacific Program.

Kennett, D., A. Anderson, M. Prebble, E. Conte and J. Southon 2006. Prehistoric human impacts on Rapa, French Polynesia. Antiquity 80:340-354.

Kirch, P.V. 1994. The wet and the dry: Irrigation and agricultural intensification in Polynesia. Chicago: University of Chicago Press.

Kirch, P.V. 1996. Late Holocene human-induced modifications to a central Pacific island ecosystem. Proceedings of the National Academy of Sciences 93:5296-5300.

Kirch, P.V., J.C. Ellison 1994. Paleoenvironmental evidence for human colonization of remote Oceanic islands. Antiquity 68:310-321.

Kirch, P.V., D.W. Steadman, V.L. Butler, J. Hather and M.I. Weisler 1995. Prehistory and human ecology in Eastern Polynesia: Excavations at Tangatatau Rockshelter, Mangaia, Cook Islands. Archaeology in Oceania 30:47-65.

McConkey, K.R. and D.R. Drake 2006. Flying foxes cease to function as seed dispersers long before they become rare. Ecology 87:271-276.

McConkey, K.R. and D.R. Drake 2007. Indirect evidence that flying foxes track food resources among islands in a Pacific archipelago. Biotropica 39(3):436-440.

Mueller-Dombois, D. and F.R. Fosberg 1998. Vegetation of the tropical Pacific islands. New York: Springer-Verlag.

Nunn, P. D. 1994. Oceanic Islands. Oxford: Blackwell.

Palmer, M.W. 1988. The vegetation and anthropogenic disturbance of Toloa Forest, Tongatapu Island, South Pacific. Micronesica 21:279-281.

Park, G. and A. Whistler 2001. The terrestrial ecology and botany of Tofua and Koa Islands in Ha'apai, Kingdom of Tonga. Report of the botanical survey of the Ha'apai Conservation Area Project of the South Pacific Biodiversity Conservation Programme, Apia, Samoa.

Parkes, A. 1997. Environmental change and the impact of Polynesian colonization: sedimentary records from central Polynesia. In P.V. Kirch and T.L. Hunt (eds) Historical ecology in the Pacific islands: Prehistoric environmental and landscape change, pp166-199. New Haven: Yale University Press.

Parkes, A., J.R. Flenely and J.T. Teller 1992. Environmental history of the Lake Vaihiria drainage basin, Tahiti, French Polynesia. Journal of Biogeography 19:431-447.

Poulsen, J. 1987. Early Tongan prehistory: The Lapita Period on Tongatapu and its relationships. Terra Australis 12 (2 volumes) 205pp Canberra.

Prebble, M. 2008. No fruit on that beautiful shore: What plants were introduced to the subtropical Polynesian islands prior to European contact? In G. Clark, F. Leach and S. O'Connor (eds) Islands of Inquiry. Colonisation, seafaring and the archaeology of maritime landscapes, pp227-251. Canberra: ANU-E Press.

Prebble, M. and J.L. Dowe 2008. The late Quaternary decline and extinction of palms on oceanic Pacific islands. Quaternary Science Reviews 27:2546-2567.

Prebble, M. and J.M. Wilmshurst 2009. Detecting initial impacts of humans and introduced species on island environments in Remote Oceania using paleoecology. Biological Invasions 11:1529-1556.

Rainey, W.E., E.D. Pierson, T. Elmqvist and P.A. Cox 1995. The role of flying foxes (Pteropodidae) in oceanic island ecosystems of the Pacific. Symposium of the Zoological Society, London 67:47-62. 
Smith, A.C. 1979, 1981, 1985, 1988, 1991: Flora Vitiensis Nova: A new flora of Fiji, Vols. 1-5. Lanai: Pacific Tropical Botanical Gardens.

Southern, W. 1986. The late Quaternary environmental history of Fiji. Unpublished PhD thesis, Australian National University, Canberra.

Spriggs, M. 1984. Early coconut remains from the South Pacific. Journal of the Polynesian Society 93:71-76.

Steadman, D.W. 2006. Extinction and biogeography of tropical Pacific birds. Chicago, University of Chicago Press.

Steadman, D.W., J. Franklin, D.R. Drake, H.B. Freifeld, L.A. Bolick, D.S. Smith and T.J. Motley 1999. Conservation status of forests and vertebrate communities in the Vava'u island group, Tonga. Pacific Conservation Biology 5:191-207.

Stevenson, J., 1998. Human impact from the palaeoenvironmental record in New Caledonia. In J.-C. Galipaud and I. Lilley (eds), Le Pacifique de 5000 a 2000 BP: Supplements a l'Histoire d'une Colonisation, pp251-259. Noumea: Orstom.

Stevenson, J., J.R. Dodson and I.P. Prosser 2001. A late Quaternary record of environmental change and human impact from Plum Swamp, New Caledonia. Palaeogeography, Palaeoclimatology, Palaeoecology 168:97-123.

Stoddart, D.R. 1992. Biogeography of the tropical Pacific. Pacific Science 46:276-293.

Sykes, W.R. 1977. The pteridophytes of 'Eua, southern Tonga. Bulletin of the Royal Society of New Zealand 17:119-152.

Sykes, W.R. 1981. The vegetation of Late, Tonga. Allertonia 2:323-353.

Thompson, C.S. 1986. The climate and weather of Tonga. New Zealand Meteorological Service Miscellaneous Publication 188. Wellington: New Zealand Meteorological Service.

van Steenis, C.G.G.J. 1979. Plant geography of east Malesia. Botanical Journal of the Linnean Society 79:97-178.

Whistler, W.A. 1991. The ethnobotany of Tonga: The plants, their Tongan names, and their uses. Bernice P. Bishop Museum Series in Botany 2:1-155.

Whistler, W.A. 1992a. Flowers of the Pacific Island seashore: a guide to the littoral plants of Hawai'i, Tahiti, Samoa, Tonga, Cook Islands, Fiji, and Micronesia. Honolulu: University of Hawaii Press.

Whistler, W.A. 1992b. Vegetation of Samoa and Tonga. Pacific Science 46:159-178.

Whistler, W.A. 1995. Waysideplants of the islands: A guide to the lowland flora of the Pacific Islands, including Hawai'i, Samoa, Tonga, Tahiti, Fiji, Guam, Belau. Honolulu: Isle Botanica.

Wiser, S.K., D.R. Drake, L.E. Burrows and W.R. Sykes 2002. The potential for long-term persistence of forest fragments on Tongatapu, a large island in western Polynesia. Journal of Biogeography 29:767-787.

Yuncker, T.G. 1959. Plants of Tonga. Bishop Museum Bulletin 220:1-283. 